\title{
PENUNJUK ARAH ABSOLUT DALAM BAHASA TONTEMBOAN
}

\section{Kevin Yeremia Robot}

kevinrobot@live.com

\section{Pascasarjana}

\section{Universitas Sam Ratulangi}

\begin{abstract}
Languages have their own fashion for indicating the location of certain objects. Generally, such languages utilizes with morphemes such as 'left', 'right', 'in front of', and 'in back of', namely relative directions. However, there are also languages which utilizes cardinal directions, such as 'north', 'south', 'west' and 'east' for indicating the location of certain objects, namely absolute directions. In addition to cardinal directions, absolute directions also utilize uphill/downhill distinction in differentiating 'up' or 'down'. Tontemboanese language is one of the languages which utilize absolute directions. This research aims to show how Tontemboanese speakers utter words in terms of spatial reference of the speakers. Through interview, it is revealed that Tontemboanese speakers utilize absolute directions to indicate the object locations, the motion of the actions, and parting phrases. In using the cardinal direction, the sun is the main source in indicating the directions.
\end{abstract}

Keywords: absolute directions, Tontemboanese.

\section{PENDAHULUAN}

Bahasa Tontemboan merupakan bahasa yang dituturkan oleh warga Minahasa, khususnya warga yang berada dalam komunitas tutur bahasa Tontemboan. Menurut Tambuwun (1986:9), bahasa Tontemboan umumnya dituturkan oleh warga-warga Kabupaten Minahasa Selatan dan sebagian kabupaten Minahasa. Secara etimologis, dalam bahasa Tontemboan, 'Tontemboan' dapat diuraikan menjadi tou (orang), in (dari), dan temboan (pegunungan), sehingga kata 'Tontemboan' sendiri berarti orang-orang dari pegunungan. Bahasa Tontemboan dianggap sebagai bahasa yang terbesar di antara bahasa Minahasa dalam segi jumlah penutur aslinya, berbeda dengan bahasa Tonsea yang dianggap sebagai bahasa Minahasa yang terbesar dari segi daerah komunitas tuturannya (Sneddon, 1970:17).

Menurut Rattu et al (1993:2), para penutur bahasa Tontemboan tersebar di berbagai kecamatan di Minahasa Induk dan Minahasa Selatan, terdiri dari Sonder, Kawangkoan, Langowan, Tompaso, Tumpaan, Tenga, Motoling, Modoinding, Tompaso Baru, dan 
Tombasian. Selain itu, terdapat juga para perantau yang berasal dari kecamatan-kecamatan di atas dan masih mampu dalam berbahasa Tontemboan.

Bahasa Tontemboan memiliki dua dialek utama, yakni dialek Matana'i dan dialek Makela'i. Tambuwun (1986:8-9) mengungkapkan bahwa dialek Matana'i dituturkan di daerah Sonder, Kawangkoan, Tareran, Tumpaan, Tombasian, Tenga, Modoinding, dan Tompaso Baru. Sedangkan dialek Makela'i dituturkan di daerah Langowan, Tompaso, dan sebagian daerah Tompaso Baru. Tidak dapat dipungkiri bahwa penentuan dan pemetaan bahasa Tontemboan dan dua dialeknya masih menuntut penelitian dialektologi yang lebih lanjut untuk dapat menentukan di mana saja suatu dialek dituturkan. Hal ini diperlukan karena ada di daerah yang termasuk dalam daerah dialek Matana'i, tetapi pada kenyataannya menuturkan bahasa Tontemboan dialek Makela'i, seperti ditunjukkan oleh Rattu et al (1993:4) bahwa desa Kanonang yang berada di daerah Kawangkoan menuturkan bahasa Tontemboan dialek Makela'i di mana seharusnya daerah Kawangkoan dikatakan menuturkan dialek Matana'i.

Rattu et al (1993:1) juga menjelaskan bahwa secara kekerabatan bahasa, bahasa Tontemboan memiliki kekerabatan dengan bahasa Tonsawang, bahasa yang dituturkan di daerah Ratahan. Sedangkan bahasa Minahasa yang lain, seperti bahasa Tonsea, Tombulu dan Toulour merupakan satu rumpun bahasa yang berbeda dengan bahasa Tontemboan. Namun, Sneddon (1970) mengungkapkan bahwa bahasa Tontemboan memiliki keterkaitan yang lebih jauh dengan bahasa Tonsawang, apabila dibandingkan dengan bahasa Tombulu, Tonsea, dan Tolour. Dengan melihat kosakata antarbahasa Minahasa, Sneddon menjelaskan persentase kata asal antara bahasa Tontemboan dan bahasa Tonsawang hanya sebesar 44\%, apabila dibandingkan dengan bahasa Tombulu dengan $61 \%$, bahasa Tonsea dengan 57\%, dan bahasa Tolour dengan 58\%. Dengan mempertimbangkan akan adanya perbedaan struktur bahasa antara bahasa Minahasa ini, Sneddon mengungkapkan bahwa bahasa Tontemboan tidak berhubungan erat dengan bahasa Tonsawang, melainkan hanya kemungkinan memiliki bahasa proto yang seasal (Sneddon, 1970:14).

Dalam makalah ini akan dijelaskan salah satu aspek linguistik, khususnya semantik, dalam bahasa Tontemboan, yakni cara penutur bahasa Tontemboan dalam merujuk ruang dan lokasi di mana hal tersebut dilakukan dengan menggunakan penunjuk arah kardinal, atau arah mata angin. Makalah ini akan mengkaji makna kata-kata arah mata angin dan melihat bagaimana penggunaan arah mata angin memberikan makna tertentu dalam ujaran. 


\section{LATAR BELAKANG}

Setiap bahasa memiliki cara untuk menunjukkan letak dari suatu benda, hal ini ditunjukkan dalam bahasa Indonesia dengan mengatakan 'kiri' atau 'kanan', serta 'depan' atau 'belakang'. Kata-kata tersebut berfungsi untuk mengidentifikasi lokasi dan sebenarnya bersifat umum di semua bahasa (Riemer, 2010:407). Hal ini bermaksud bahwa sebenarnya ungkapan penunjukan lokasi atau arah memang bersifat umum dan setiap bahasa memiliki caranya sendiri dalam mengungkapkannya. Namun, konsep mengenai 'kiri' dan 'kanan', atau yang dikenal dengan arah relatif (relative direction), tidak mutlak berlaku secara universal di setiap bahasa. Hal ini ditunjukkan dengan adanya bahasa yang menggunakan sistem yang berbeda dari bahasa Indonesia atau Inggris dalam menjelaskan lokasi dan arah suatu benda. Terdapat beberapa bahasa yang menggunakan sistem arah kardinal (cardinal direction) dalam menunjukkan lokasi, arah kardinal ini seringkali disebut dengan arah absolut (absolute direction).

Arah relatif merupakan sistem identifikasi ruang yang menggunakan informasi mengenai pengaturan tubuh dari pembicara, seringkali dari sisi penutur, seperti 'kiri', 'kanan', 'depan', dan 'belakang', contohnya 'di sebelah kiri (saya)'. Sistem ini merupakan sistem yang memiliki aspek yang tak tertanda (unmarked). Lalu, arah absolut merupakan sistem identifikasi ruang tidak bergantung pada posisi tubuh pembicara, tetapi bergantung pada fitur geografi yang tetap, seperti pembedaan 'naik gunung' (uphill) dan 'turun gunung' (downhill), dan arah kardinal atau mata angin, seperti 'utara', 'selatan', 'barat', dan 'timur'. Sistem arah absolut pun dapat dikatakan sebagai sistem yang tertanda (marked) karena dapat dikatakan bahwa penggunaan sistem ini tidak secara umum digunakan. Jadi, dalam arah absolut, ungkapan seperti 'bukuku ada di sebelah utara pulpen' dianggap sebagai ungkapan yang umum dalam mengidentfikasi lokasi. Sistem arah absolut ditemukan dalam beberapa bahasa seperti Arrente, Guugu Yimithirr, Jawa, Bali, hingga salah satu bahasa Minahasa, yakni bahasa Tontemboan, yang akan dibahas selanjutnya dalam makalah ini (Pederson et al, 1998; Riemer, 2010; Haviland, 1998; Harimurti, 2001; Wassmann, 1998; Tambuwun, 1985).

Jadi, dalam penelitian ini akan dilihat bagaimana arah absolut yang dibatasi pada arah mata angin (cardinal directions) dan pembatasan naik-turun gunung (uphill-downhill distinction) yang dijelaskan oleh Riemer (2010:409).

Penggunaan arah mata angin dapat dilihat contohnya terlebih dalam bahasa Bali, yakni sebagai berikut: 
(Bahasa Bali)

(1) Daj

$\begin{array}{lllll}\text { Dajan } & \text { rurung-e } & \text { ada } & \text { anak ng-adep } & \text { kembungan. } \\ \text { Di selatan } & \text { jalan-nya } & \text { ada } & \text { orang jual } & \text { balon }\end{array}$

"Di selatan jalan ada orang yang menjual balon."

(2) I

$$
\text { Belog }
$$

ulung di delod

pangkung-e.

Artikel

Belog

jatuh di utara

jurang

"Belog jatuh di sebelah utara jurang"

(3) Dauh tukade tusing ada yeh.

Utara sungai tidak ada air

"Di utara sungai tidak ada air."

(4) Dangin tiange umah-ne.

Timur saya rumah(posesif)

Rumahnya di sebelah timur rumah saya.

Selanjutnya di bawah ini juga terdapat contoh dalam bahasa Arrente, salah satu bahasa di Australia seperti yang ditunjukkan oleh Riemer (2010:409):

(Bahasa Arrente)

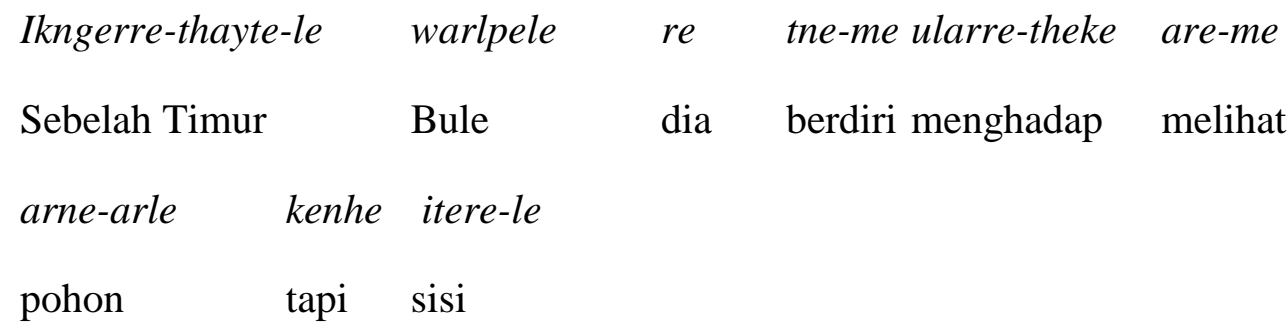

"Bule itu berdiri di sebelah timur dan melihat ke arah kita, tapi pohonnya berada pada sisinya."

Selain pada contoh bahasa Bali dan Arrente di atas, dalam bahasa Tontemboan sendiri, arah mata angin diungkapkan dengan kata, monge 'utara', meko 'selatan', mako 'barat', dan mico 'timur'. Dan penggunaan arah mata angin dalam bahasa Tontemboan akan dibahas selanjutnya dalam makalah ini. Alasan kajian arah mata angin dalam bahasa Tontemboan dipilih sebagai topik kajian karena aspek ini seringkali menurut peneliti menarik untuk dibahas dan perlu untuk pengembangan kajian semantik, khususnya dalam kajian makna kata.Kajian mengenai penunjukan lokasi melalui arah kardinal atau mata angin kurang diperhatikan sebagai kajian makna kata di mana hal ini juga serupa yang dikatakan oleh Haviland (1998:26), oleh karena itu, perlunya penelitian lebih lanjut mengenai penggunaan sistem arah kardinal, terutama dalam bahasa Tontemboan. Dengan 
penelitian ini, peneliti melihat akan pentingnya kajian mengenai makna kata, khususnya mengenai arah absolut karena dianggap dapat memberikan pandangan yang baru mengenai cara bagaimana penutur bahasa Tontemboan menjelaskan lokasi suatu objek atau arah dari suatu tindakan yang dilakukan oleh penutur. Selain itu, penelitian ini memberikan kesempatan bagi peneliti untuk memahami konsep arah pada penutur bahasa Tontemboan dan memberikan kesempatan kepada peneliti untuk mempelajari bahasa Tontemboan secara lebih mendalam.

Penelitian ini bermaksud untuk menjelaskan konsep identifikasi ruang yang ada dalam bahasa Tontemboan yang nantinya dapat menjadi pengembangan dalam kajian bahasa Tontemboan, khususnya kajian semantik bahasa Tontemboan dan menjadi suatu langkah dalam pemertahanan bahasa daerah yang sebenarnya perlu dilakukan oleh setiap lapisan masyarakat komunitas tutur (speech community).

\section{MASALAH YANG DITEMUKAN}

Penelitian-penelitian yang ada mengenai bahasa Tontemboan seperti Struktur Bahasa Tontemboan oleh Ticoalu et al., Tatabahasa Tontemboan oleh Tambuwun dianggap kurang memperhatikan aspek penggunaan arah mata angin, yang sebenarnya menjadi salah satu aspek penting dalam bahasa Tontemboan karena memiliki konsep yang berbeda dengan bahasa Melayu-Manado dan bahasa Indonesia perihal identifikasi ruang. Selain itu, dalam Introducing Semantics oleh Riemer membahas cara identifikasi ruang dalam bahasa tertentu dengan menggunakan arah mata angin, tetapi penulis menemukan penggunaan arah mata angin tidak hanya terbatas pada kalimat pernyataan lokasi, tetapi juga dapat digunakan sebagai salam, khususnya untuk berpisah, yang akan dibahas lebih lanjut dalam bagian pembahasan.

Dari masalah yang ditemukan pada penelitian dan literatur sebelumnya, maka penelitian ini akan membahas lebih mendalam mengenai arah absolut dalam bahasa Tontemboan yang sebelumnya belum dibahas secara detail.

\section{METODE PENELITIAN}

Dalam pengumpulan data, penulis melakukan wawancara kepada beberapa narasumber yang memiliki kemampuan dalam berbahasa Tontemboan, memiliki alat ucap yang lancar, dan sehat secara jasmani dan rohani. Wawancara dilakukan dengan memberikan pertanyaan secara ringkas status penggunaan bahasa Tontemboan, lalu 
memberikan pertanyaan mengenai arah mata angin dalam bahasa Tontemboan, serta membahas penggunaan kata arah mata angin dalam kalimat dan percakapan antarpenutur bahasa Tontemboan.

Peneliti memilih anggota keluarga dari peneliti yang juga merupakan penutur bahasa Tontemboan, hal ini dilakukan demi kemudahan akses dalam menjalankan penelitian di mana wawancara penelitian dapat berjalan secara lebih fleksibel. Bentuk penelitian ini dapat dikatakan, dengan istilah Milroy, merupakan sebuah kajian awal (pilot studies) dari penelitian yang lebih besar, yakni dengan menggunakan wawancara dan daftar kata (Milroy, 1989). Jadi, penelitian ini menjadi suatu langkah awal terhadap penelitian bahasa Tontemboan yang lebih besar cakupannya maupun lebih rinci.

Selain itu, peneliti juga menggunakan data sekunder berupa literatur yang membahas mengenai tata bahasa Tontemboan. Data sekunder tersebut dijadikan sebagai referensi bagi peneliti untuk dapat menguatkan data-data primer yang didapatkan melalui wawancara dengan informan.

\section{HASIL DAN PEMBAHASAN}

Bahasa Tontemboan merupakan salah satu bahasa yang menggunakan sistem arah absolut dalam mengidentifikasi lokasi atau ruang. Namun, selain arah mata angin, bahasa Tontemboan juga memiliki kata ka'mbiri "kiri" dan kakan "kanan" yang menunjukkan juga bahasa Tontemboan juga menggunakan sistem arah relatif. Akan tetapi, berdasarkan penelitian, dapat dikatakan bahwa penggunaan sistem arah absolut lebih sering dipakai dalam percakapan bahasa Tontemboan. Lalu, pembedaan arah absolut melalui arah naikturun gunung juga digunakan dalam bahasa Tontemboan, hal ini juga digunakan untuk menggunakan pembedaan lokasi atas-bawah.

Pada bagian sebelumnya telah dijelaskan bahwa arah mata angin dalam bahasa Tontemboan adalah monge "utara", meko "selatan", mako "barat", dan mico "timur". Arah mata angin ini dapat dilihat pada bagan berikut: 


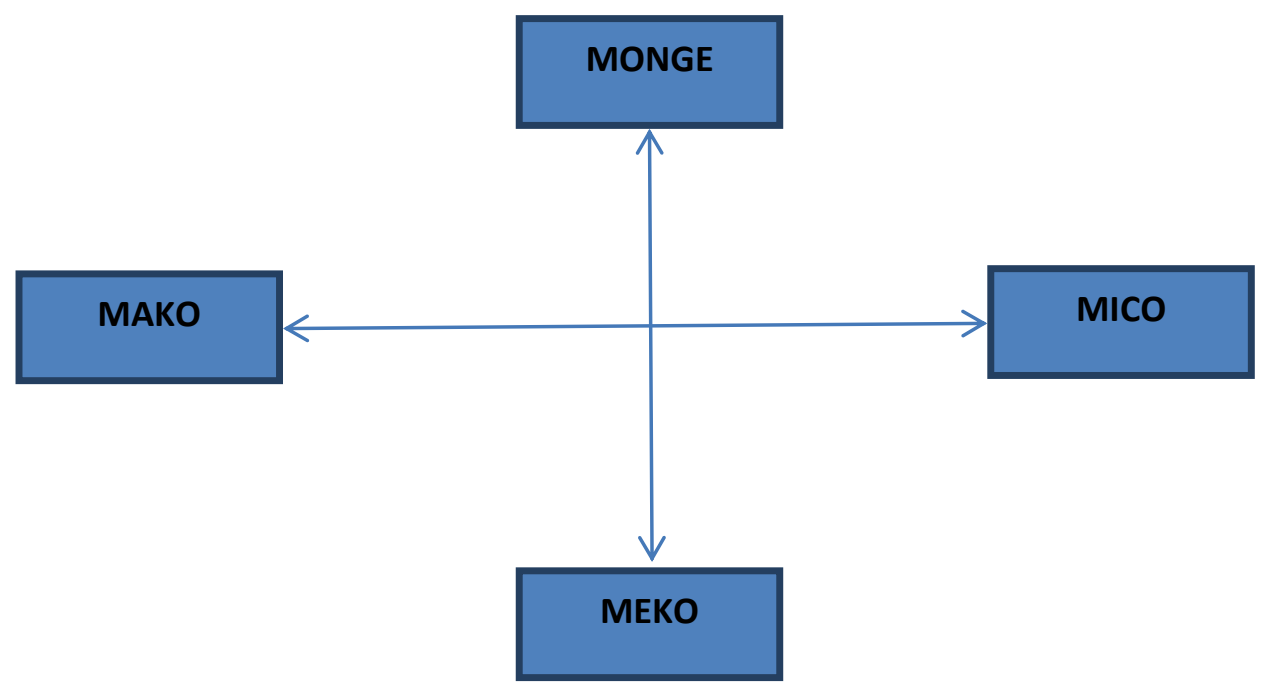

Bagan 1. Arah Mata Angin Bahasa Tontemboan

\section{Lokasi Objek}

Dalam berbicara lokasi suatu benda, penutur bahasa Tontemboan cenderung menjelaskan dengan menggunakan arah kardinal, contohnya pada saat peneliti menanyakan lokasi kacamata yang saat itu berada di sebelah kanan vas bunga (dari perspetif peneliti), informan mengatakan lokasi kacamata tersebut sebagai berikut

(1) Eng kacamata amicona in vas bunga "Kacamata ada di sebelah timurvas bunga."

(2) Eng kacamata ang kambiri in vas bunga "Kacamata ada di sebelah kiri vas bunga."

Dan memang, setelah diperhatikan lokasi kacamata tersebut berada di arah timur vas bunga. Dengan menggunakan arah absolut, baik peneliti maupun informan, yang saat itu duduk saling berhadapan, sebenarnya dapat mengungkapkan lokasi kacamata tersebut dengan menggunakan kalimat pada butir (1) karena baik dari sisi peneliti dan informan, letak kacamata tersebut tetap berada di sebelah timur vas bunga. Namun, lokasi kacamata tersebut dapat juga diganti dengan menggunakan sistem arah relatif, akan tetapi penggunaan kata akan berubah menurut sudut pandang peneliti atau informan, jadi amicona dapat diganti dengan ang kambiri "di sebelah kiri" atau ang kakan "di sebelah kanan" tergantung dari sudut pandang pembicara yang sebenarnya telah diungkapkan pada butir (2). Lokasi-lokasi dengan arah mata angin dalam bahasa Tontemboan adalah sebagai berikut: 
(3) Amongena "di sebelah utara(nya)"

$\begin{array}{ll}\text { Amekona } & \text { "di sebelah selatan(nya)" } \\ \text { Amakona } & \text { "di sebelah barat(nya)" } \\ \text { Amicona } & \text { "di sebelah timur(nya)" }\end{array}$

Namun, ditemukan juga bahwa penggunaan arah kardinal tidak digunakan untuk membedakan lokasi bagian tubuh di mana informan menggunaan pembedaan arah relatif dalam menentukan lokasi bagian tubuh. Jadi, sesuai dengan penjelasan informan, contoh penggunaan arah relatif yang diungkapkan adalah sebagai berikut:

(4) Keicei ka'mbiri/kakan

Kama ka'mbiri/kakan

\author{
"kaki kiri/kanan" \\ "tangan kiri/kanan"
}

Artinya, penutur tidak membedakan lokasi kaki dan tangan dengan mengatakan "kaki arah Timur", atau pun "tangan arah Barat". Penggunaan frase tersebut ditemukan dalam kalimat yang dituturkan oleh informan sebagai berikut:

(5) Sa kuman, kuman ing kama kakan. "Kalau mau makan, makan dengan tangan kanan."

Dari kalimat di atas dapat dilihat penggunaan arah relatif juga sebenarnya bukan tidak digunakan sepenuhnya oleh penutur bahasa Tontemboan, tetapi terdapat hal-hal tertentu, dalam hal ini bagian tubuh, yang memerlukan pembedaan arah dengan menggunakan arah relatif.

Mengenai arah kardinal, informan menjelaskan bahwa sebenarnya yang menjadi patokan awal adalah letak matahari. Matahari dijadikan sebagai patokan bagi penutur bahasa yang menggunakan arah kardinal sebagai penunjuk lokasi. Tetapi, penutur telah mengetahui letak arah kardinal secara bawaan di mana sejak lahir informan telah terbiasa dengan menggunakan arah mata angin untuk merujuk lokasi suatu objek. Ketika ditanyai arah mata angin kepada informan, informan pun dapat langsung mengidentifikasi arah mata angin dengan benar. Hal ini dikonfirmasi oleh peneliti dengan menggunakan kompas yang ada pada ponsel peneliti serta dengan melihat arah matahari berada. Selanjutnya, apabila berada di daerah yang baru, dikatakan oleh informan bahwa mereka akan melihat arah atau lokasi matahari terlebih dahulu dan menentukan arah kardinal untuk dijadikan 
penunjukan lokasi, tetapi apabila berada di daerah yang telah dikenal, informan terlihat mengetahui secara refleks arah mata angin.

Namun, apabila diamati, informan seringkali kurang tepat dalam mengidentifikasi arah mata angin dalam bahasa Indonesia, maksudnya arah mata angin sering tertukar, tetapi selalu merujuk pada arah mata angin yang benar apabila dengan mengujarkan dalam bahasa Tontemboan.Hal ini dapat dipahami karena penutur merupakan penutur asli bahasa Tontemboan dengan bahasa Melayu Manado sebagai bahasa kedua mereka.

\section{Arah Tindakan}

Selain lokasi, penggunaan arah kardinal juga digunakan untuk mengungkapkan arah tindakan, seperti pergi, datang, dan duduk. Hal ini dilakukan dengan melekatkan aspek arah tindakan, dalam hal ini arah mata angin, setelah kata kerja yang dimaksud, contoh dari kata kerja yang memuat arah mata angin dapat dilihat pada butir (6) di bawah ini:

(6) lumukut-mako "duduklah di sebelah barat." monge ko "pergilah kau ke sebelah utara." maya-monge yaku "saya berjalan ke arah utara."

Ungkapan yang terdapat dalam butir (6) menunjukkan arah tindakan yang dilakukan oleh penutur atau diperintahkan kepada pendengar. Arah tindakan seperti ini mungkin juga dapat dilihat dalam bahasa Melayu Manado seperti klausa imperatif tutu akang kasana/kamari "tutuplah (ke sana/ke sini)." Arah tindakan dalam bahasa Tontemboan juga dapat terlihat dalam peristiwa tutur yang diungkapkan sebagai berikut:

(7) A: Mawisa pe’ ko? "Mau ke mana kamu?"

B: Monge pe' aku am pasar. "Saya mau pergi ke arah utara, ke pasar."

A: $O$, maleilek a lalan. "Oh, hati-hati di jalan."

Dari percakapan di atas, ditunjukkan bahwa penutur memberikan indikasi arah tujuan1nya dengan lebih rinci menggunakan arah mata angin, dan pengindikasian tersebut membuat kata benda tersebut diverbalisasikan dan memiliki makna berpergian menuju arah tersebut. 
Meskipun tidak menggunakan arah kardinal, tetapi dapat dilihat juga terdapat arah tindakan dalam hal ini apakah mendekati atau menjauhi penutur.Ungkapan di atas juga serupa ditemukan dalam bahasa Jawa di mana contohnya ditunjukkan dalam Kridalaksana (2001:32) sebagai berikut:

(Bahasa Jawa Krama)

$\begin{array}{lll}\text { (8) Piyambakipun } & \text { nembè } & \text { ngalèr } \\ \text { dia } & \text { sedang } & \text { utara }\end{array}$

"Dia sedang menuju ke utara."

Selain mata angin, penutur bahasa Tontemboan juga menggunakan arah absolut dengan membedakan arah naik/turun ke atau dari gunung, hal ini diungkapkan dengan kata mange "naik" dan mio' "turun". Kata ini dapat bermakna pergi naik/turun, yang seringkali digunakan oleh penutur bahasa Melayu-Manado dengan mengatakan:

(9) kita mo (nae Tondano)/(turun Manado) ini "saya mau pergi (naik) ke Tondano/(turun) ke Manado".

\section{Pembedaan Arah Naik/Turun Gunung (Uphill/Downhill Disctinction)}

Selain menunjukkan pergerakan, penggunaan arah naik/turun juga dapat bermakna atas atau bawah, seperti amangena "di atas" dan amio'na "di bawah". Sesuai pengamatan, informan mengatakan letak kacamata yang berada di atas meja dengan ungkapan:

$$
\text { eng kacamata amangena im meja "kacamata ada di atas meja." }
$$
en selop amio'na im meja "sandal ada di bawah meja."

Dalam penggunaan butir (10), sebenarnya kata amangena yang memiliki kata dasar ange memiliki makna "naik ke gunung/atas", dan apabila diderivasikan menjadi verba, maka akan bermakna "pergi ke atas/ke arah gunung", begitu juga apabila diaplikasikan pada kata amio 'nayang berarti “turun dari gunung." Mange atau ma'ange merupakan verba depreposisional karena sebelumnya kata amangena merupakan sebuah preposisi. Penggunaan verba tersebut dapat dilihat pada penggalan kalimat berikut: 
B: Ma'angeo sia an Tondano "Dia sudah mulai naik ke Tondano."

Dari percakapan di atas, dapat dilihat bahwa sebenarnya konteks percakapan bahwa kedua penutur sedang berada di daerah Manado, dan penggunaan kata ma'ange dipakai untuk menunjukkan bahwa orang yang dicari telah pergi ke arah gunung, yakni di Tondano yang dianggap berada di daerah lebih tinggi dari Manado, sehingga penutur B dalam butir (11) menggunakan kata ma'ange yang berarti "naik ke arah gunung." Jadi, dapat dikatakan bahwa perlunya pengetahuan dasar mengenai letak geografis suatu daerah sehingga dapat ditentukan pembedaan arah baik arah atas atau bawah, sehingga dapat memilih kata yang tepat.

\section{Salam Perpisahan}

Lalu, terdapat juga hal yang menarik dalam penggunaan arah mata angin dalam bahasa Tontemboan. Penutur bahasa Tontemboan juga menggunakan arah mata angin sebagai salam perpisahan. Maksudnya adalah ketika seorang penutur hendak pergi ke suatu tempat, penutur tersebut berpisah dengan menggunakan arah mata angin sebagai ungkapan pamit undur diri, contohnya dalam konteks penutur berada di daerah Airmadidi dan hendak melanjutkan perjalanannya ke kota Manado, penutur akan berpamitan dengan menggunaka kata maakom "(saya) mau pergi ke arah Barat". Jadi, terdapat konfiks ma-m yang diisi dengan kata dasar mata angin (onge, eko, ako, ico) menjadi maongem, maekom, maakom, dan maicom dan juga dengan kata dasar arah naik/turun (ange, io') sehingga menjadi ma'angem dan maio'm/mio'm. Selain konstruksi seperti itu, penutur juga menggunakan ungkapan:

$$
\text { mico pe’ aku/kami.“Saya/kami hendak ke utara.” }
$$

Dari butir (12) di atas, dapat dikatakan bahwa ungkapan ini juga memiliki fungsi sebagai ungkapan pamit. Jadi, tergantung dari arah kepergiannya, penutur akan berpamitan dengan menunjukkan arah mata angin yang sesuai dengan tujuannya dengan menggunakan ungkapan di atas.Sebenarnya, ujaran dalam butir (12) berbeda dengan butir (7) apabila melihat konteks bahwa dalam butir (7) merupakan jawaban atas pertanyaan yang ditanyakan, sedangkan butir (12) diungkapkan tanpa ada pertanyaan terlebih dahulu dari pihak petutur, sehingga dapat dikatakan sebagai ungkapan atau salam perpisahan. 
Penggunaan salam perpisahan juga terlihat pada arah atas atau bawah, ditemukan bahwa apabila penutur hendak pergi ke atas atau ke arah bawah, penutur menggunakan arah mange dan mio' untuk berpisah. Penggunaan konstruksi tersebut dapat dilihat pada contoh berikut: mio'm re'en kami "Kami mau turun dulu."

Pada butir (13) dapat dilihat konteksnya bahwa penutur yang mengujarkan kalimat ini berada di daerah Winangun, yang berada di daerah bukit, dan akan kembali ke rumahnya di daerah jalan Bethesda, yang seperti diketahui berada di dataran rendah. Karena daerah jalan Bethesda relatif lebih rendah apabila dibandingkan dengan daerah Winangun, maka penutur akan berpamitan dengan menggunakan kata mio'm yang bermakna turun dari arah gunung, atau dari arah yang lebih tinggi. Jadi, dalam pembedaan arah atas dan bawah cenderung relatif dan harus ada perbandingan yang disetujui bersama secara tidak sadar oleh para penutur bahasa Tontemboan.

Akan tetapi, informan juga mengatakan bahwa sebenarnya selain dengan menggunakan arah kardinal, penutur juga menggunakan ungkapan alternatif:

$$
\text { mangem yaku/kami“'Saya/kami pergi dulu” }
$$

Dapat dilihat pada penggalan kalimat di atas bahwa pada dasarnya ungkapan tersebut tidak memuat arah ke mana penutur tersebut hendak pergi. Ungkapan ini dikatakan oleh informan dapat digunakan pada situasi untuk berpisah dari petutur, apabila penutur hendak pergi ke suatu tempat. Ungkapan ini tidak memuat arah absolut, sehingga tidak dapat ditentukan apakah penutur hendak pergi ke timur atau barat, ataupun naik ke gunung, atau turun ke bawah. Meskipun sebenarnya, memuat kata dasar ange yang bermakna naik ke atas gunung, tetapi ditemukan bahwa kata mange juga dapat dipakai untuk mengungkapkan makna pergi secara umum tanpa mengindahkan arah tindakan.

Tambahan pula, ketika berpamitan ke Jakarta, informan akan mengacu dengan pembeda arah naik/turun bukan dengan arah mata angin, yakni ke Selatan, sehingga penutur akan berpamitan dengan ungkapan ma'angem an Jakarta. Hal ini dikarenakan bahwa ketika hendak ke Jakarta, penutur yang berpamitan menggunakan pesawat dan naik ke awan terlebih dahulu, sehingga digunakan pembeda arah naik/turun. Jadi, dalam komunitas tutur bahasa Tontemboan, untuk berpamitan, penutur harus mengidentifikasi arah tujuan perginya, meskipun tidak spesifik dengan mengungkapkan tempat, tetapi 
penutur akan mengungkapkan arah mata angin tujuannya dari tempat ia mengungkapkan salam.

Namun, penelitian ini masih dapat dikembangkan lebih lanjut lagi dengan melihat sisi kognisi penutur ditinjau dari aspek linguistik. Selain itu, penelitian ini masih dapat dikembangkan lebih besar lagi cakupan sumber data agar penggunaan arah absolut dalam bahasa Tontemboan dapat dipahami dan diteliti secara lebih mendalam.

\section{SIMPULAN}

Berdasarkan hasil pengamatan di atas, dapat dikatakan bahwa bahasa Tontemboan memiliki sistem arah relatif dan absolut, tetapi penggunaan sistem arah absolut lebih umum digunakan oleh penutur bahasa Tontemboan. Penutur bahasa Tontemboan akan menggunakan arah mata angin amongena "utara", amekona "selatan", amakona "barat", amicona "timur" untuk menunjukkan letak suatu benda. Selain itu, arah mata angin menunjukkan arah tindakan penutur terhadap sesuatu, seperti maya-monge "berjalan ke arah utara". Lalu, sebagai ungkapan pamitan, contohnya maakom "saya mau pergi ke arah barat".

Selain mata angin, penutur bahasa Tontemboan juga menggunakan sistem arah absolut dengan pembedaan arah naik/turun gunung (uphill/downhill) yang juga dapat bermakna naik/turun dan juga bermakna atas/bawah, seperti mange "naik (ke gunung)" mio' "turun (dari gunung)". Penggunaan arah absolut ini juga menunjukkan arah pergerakan dari tindakan yang dituturkan apakah berada pada lokasi atas atau bawah dari penutur.

Selain itu, arah absolut juga menunjukkan arah tindakan dari penutur seperti mayamonge "berjalan ke arah utara", lumukut-mako "duduk di sebelah barat", dan sebagainya. Penggunaan arah absolut dapat menunjukkan arah yang hendak dilakukan oleh para penutur.

Akhirulkalam, dapat dikatakan bahwa sebenarnya penunjukan lokasi tidak selalu menggunakan arah relatif, seperti kiri dan kanan, yang sebenarnya umum dalam bahasa, tetapi terdapat juga bahasa yang menggunakan arah absolut, salah satunya arah mata angin untuk menunjukkan lokasi. Selain itu, penelitian ini juga dapat membuka penelitian lebih lanjut mengenai makna kata bahasa Tontemboan, dan juga penelitian linguistik kognitif terhadap pemahaman ruang para penutur bahasa Tontemboan. 


\section{DAFTAR PUSTAKA}

Apituley, Leo. A. et al. 1991. Struktur Lisan Bahasa Tontemboan. Departemen Pendidikan dan Kebudayaan. Jakarta.

Haviland, John. 1998. Guugu Yimithirr Cardinal Direction. Ethos 26 (1): 25-47.

Kridalaksana, Harimurti. 2011. Kamus Linguistik. Gramedia Pustaka Utama. Jakarta.

Kridalaksana, Harimurti et al. 2001. Wiwara: Pengantar Bahasa dan Kebudayaan Jawa. Gramedia Pustaka Utama. Jakarta.

Pederson, Eric et al. 1998. Semantic Typology and Spatial Conceptualization. Language 74 (3): 557-589.

Milroy, Leslie. 1989. Observing \& Analyzing Natural Language. Basil-Blackwell. Inggris. Perutu, Stelnie H. 2015. Dari Opa Sampai Semaput: Suatu Kajian Linguistik Antropologi. Gama Media. Yogyakarta.

Rattu, A.B.G. et al. 1993. Morfologi dan Sintaksis Bahasa Tontemboan. Depdikbud. Jakarta.

Riemer, Nick. 2010. Introducing Semantics. Cambridge University Press. Inggris.

Schwarz, J. A. T et al. 1908.Hoofdstukken uit de Spraakkunst van het Tontemboansch. Martinus Nijhoff. Den Haag.

Schwarz, J. A. T. 1907.Tontemboansche Teksten. E. J. Brill. Leiden.

Schwarz, J. A. T. 1908.Tontemboansch-Nederlansch Woordenboek met NederlandschTontemboansc Register. Martinus Nijhoff. Den Haag.

Sneddon, James. 1970. Languages of Minahasa. Oceanic Linguistics 9 (1): 11-36.

Tambuwun, E.M. 1986. Tatabahasa Tontemboan. Yayasan Budaya Tontemboan. Manado. Ticoalu, H. Th. Lomban, et al. 1984. Struktur Bahasa Tontemboan. Depdikbud. Jakarta. Tuwo, Frans Lapod et al. 2010. Kamus Tontemboan. Institut Seni Budaya Sulawesi Utara. Manado. 
Wassmann, Jurg \& Pierre R. Dasen. 1998. Balinese Spatial Orientation: Some Empirical Evidence of Moderate Linguistic Relativity. The Journal of the Royal Anthropological Institute 4 (4): 689-711.

Wijana, I Dewa Putu. Perilaku Empat Kata Penunjuk Arah dalam Bahasa Bali. Fakultas Ilmu Budaya Universitas Gadjah Mada. Diakses pada tanggal 21 Mei 2018.http://sastra.um.ac.id/wp-content/uploads/2010/01/008-I-Dewa-Putu-Wijana-UGM$\underline{\text { Perilaku-Empat-Kata-Penunjuk-Arah-dalam-Bahasa-Bali }}$ 